\title{
Spa and Wellness Tourism in Slovakia (A Geographical Analysis)
}

\section{Anton Kasagranda ${ }^{1,2} /$ Daniel Gurňák ${ }^{1}$}

e-mail: kasagrandaa@gmail.com, gurnak@fns.uniba.sk

${ }^{1}$ Department of Regional Geography, Planning and Environment, Faculty of Natural Sciences, Comenius University in Bratislava, Bratislava, Slovakia

${ }^{2}$ Payments Department, Section of European Funds, Ministry of Finance of the Slovak Republic, Bratislava, Slovakia

Kasagranda, A., \& Gurňák, D. (2017). Spa and Wellness Tourism in Slovakia (A Geographical Analysis). Czech Journal of Tourism, 6(1), 27-53. DOI: 10.1515/cjot-2017-0002.

\begin{abstract}
Spa industry is presently an inherent part of Slovak tourism. For this reason, it has become a major interest of scientific and professional literature (economics, management, sociology, or geography). The main topic of this paper is the evaluation of tourism in Slovakia through a geographic analysis. This paper briefly evaluates the development and the importance of spa, spa tourism and wellness and their main research areas and issues. Furthermore, the primary sources of tourism development, the overview of spa tourism and the wellness resorts, the accommodation establishments and the visitation rate are evaluated as well. In conclusion, functional and spatial typification of spa tourism and wellness in Slovakia is presented. The structure of the paper is designed to be appropriate for a comparison with $\mathrm{V} 4$ countries.
\end{abstract}

\section{Keywords}

spa tourism, wellness tourism, regional and resort analysis, Slovakia

JEL classification: L83, Z32 


\section{Introduction}

The tradition of spa industry in Slovakia, according to the available information, dates back to the arrival of the Romans to this territory and is therefore an inseparable part of the history of the country. Since this period, the population has become well aware of the high quality and the healing properties of the natural springs. The spas were primarily created for medical purposes. The present form of spa tourism in Slovakia began to develop especially after the 1990's. During this period, the "complementary" form (kind) of spa, called wellness, started to develop. For the reason mentioned above, wellness and spa are presented as one type of tourism within the typization of tourism. (Vystoupil et al. 2016; Kasagranda, 2016). The spa and wellness compose a significant share within the structure of tourism in Slovakia, especially in the context of the evaluation of tourist overnight stays and revenues.

The main goal of this paper is the evaluation and identification of spatial differentiation of spa and wellness tourism and its resorts in Slovakia. Furthermore, this paper presents methodology, basic research questions of geographic research in spa and wellness tourism in Slovakia, brief assessment of development of spa and wellness tourism, analysis of primary sources, identification of resorts of spa and wellness tourism and infrastructure of accommodation facilities and visitation rate. Finally, functional and spatial typification of spa and wellness tourist resorts is evaluated.

\section{Literature Review and Theoretical Basis}

As an important part of tourism, spa and wellness are relatively frequently discussed issues (Smith \& Puczkó, 2008; Dorocki \& Brzegowy, 2014; Hall, 2003; Smolová \& Szczyrba, 2005). Stănciulescu et al. (2015) focus on the differences between spa and wellness. Gúčik et al. (2016) reflect on the changes in spa tourism. This topic is given relatively much attention even in Europe and discussion is focused on time-space changes at the country level (Gustavo, 2010; Erdeli et al., 2011; etc.).

The topic of spa and wellness in Slovakia has been given some attention for the last 10 years (Eliašová, 2015, 2016; Gúčik et al., 2016, Marčeková et al., 2015, etc.). These authors primarily dealt with the economic aspects of spa and wellness and look for signs of changes in the spa and health tourism. Matlovičová et al. (2013) monitored spa in Slovakia in the context of change. Kulla (2011) focused his paper on the evaluation of trends and perspectives of Spa tourism in Slovakia and focused on the changes in guests' behaviour. The author also compared structure and infrastructure of spa tourism between the era of socialism and present. Otrubová (1999) analysed a number of accommodation establishments and tourists (respectively patients) and provided the forecast of development in the near future. Those have been partially fulfilled. Čuka and Šenková (2012) considered spa and wellness to be one of the main types of tourism in Slovakia. Other authors took similar stance, e.g. Mariot (1983) (one of the most important tourism geographers in Slovakia), respectively, Cákoci (2013), Cákoci et al. (2014), Weiss et al. (2005). 
Vystoupil et al. (2016) or Kasagranda (2016) created detailed typification of tourist resorts in Czechia and Slovakia. They considered the spa tourism to be one of the most important types of tourism in Slovakia. The definition of wellness as a part of tourism is questionable. Wellness is often referred to as a trend in the development of tourism (Žoncová et al., 2015). Possibilities and assumptions of development of wellness, especially in relation to climate, were pointed out by Lauko et al. (2015). No definition of the concept of wellness has been created in Slovak geography that would be accepted by geographical community. Consequently, the use and correctness of the term wellness is often questioned in geographical literature, and many authors tend to avoid it.

Furthermore, it is necessary to draw attention to other papers (bachelor, diploma or dissertation thesis) that focused on spa tourism and its spatial differentiation in Slovakia and Czechia (Jurčišinová, 2016; Zelenáková, 2014; Sudíková, 2009; Dubcová, 2014; or Kasagranda, 2016). These papers were created under the guidance of the authors and under the unified methodology used by the authors.

Additionally, Mariot (1983) created complex elaboration of the development and importance of spa and wellness tourism in Slovakia. This author also elaborated on the importance of unified definition and on the importance of the search for answers to the main research questions. Other authors followed Mariot's research, for example, Plesník (2008), Matlovičová et al. (2013) or Krogmann (2005). The contributions by Fialová and Orosz (2012), and Eliašová (2009) are also very inspirational. These authors concentrated their research on the development of spa and wellness tourism in Slovakia.

The concept of "tourist resort", in the terms of this paper, is used similarly to the concept used by Mariot (2001) and other authors that followed his example, e.g. Vystoupil et al. (2011, 2016) or Kasagranda (2016). The concept of "resorts" is understood as an administrative unit (municipality), which has accommodation establishment and has attractiveness for tourist activity. The concept of "type of tourism" is used as a unifying component for both the concepts of kinds and forms of tourism (discussed by many authors, e.g. Mariot (1983), Plesník (2008), or Vystoupil et al. (2011, 2016)). The type of tourism includes both characteristics and is defined as a broader concept.

\section{Methodology}

The significance of tourist regions and their resorts is measured by two sets of indicators. The first indicators are the indicators of capacity. These measurements are among the statistical monitoring recommendations for the EU countries, e.g. number of tourist and recreational beds (e.g. beds in collective accommodation establishments, private beds, beds in individual recreation - chalets and cottages). The second sets of indicators are the indicators of performance - e.g. number of guests, number of overnight stays, the number of days spent in accommodation facilities, and subsequently, the number of job opportunities and its total revenue (Vystoupil et al., 2016).

It is necessary to mention that the paper was structured according to the requirements of the main editor of this journal, in terms with the method of Vystoupil et al. (2006, 
2011). The intention was to contribute to a monothematic journal issue. The authors of this monothematic journal attempt to create a broader and methodically unified database of V4 countries and their spa and wellness tourism.

Valorisation of primary (natural) resources and the potential for the development of spa and wellness tourism is based on the functional-chronological paradigm which was created and developed by Mariot (1983). Studies by Franko et al. (1995), Lauko (1997), Masarovičová (2014, 2015), and Kršák et al. (2009) constitute the main theoretical background of this paper as they help to see the issue from a wider point of view.

The identification and the definition of spa and wellness tourist resorts were based on the materials issued by the Ministry of Health of the Slovak Republic (2016), Act no. $538 / 2005$ and by the regulations of the Government of the Slovak Republic. All these materials are in accordance with the methodology of studies created by the "Brno research school under the guidance of Vystoupil". Similarly, this applies to the research teams under his guidance (e.g. Vystoupil et al., (2006, 2011, 2016), or Kasagranda (2016)). Studies of these authors were used for an overview of spa and wellness resorts, as well as for an overview of accommodation infrastructure and the number of guests/tourist (domestic and foreign) of spa and wellness resorts. The database primarily consists of the internal data of the Statistical Office of Slovak Republic [SO SR] (2016) or from Slovakia Travel Agency (2016) that started to work recently. Information on mass accommodation facilities (number of facilities, rooms and bed capacity in spa and wellness tourist resorts) is analysed in a ten-year period of 2006-2015. This paper identifies several key indicators such as the number of guests, the number of overnight stays, and the share of visitation on the total number of guests in Slovak tourism and the total revenue from spa and wellness tourism. The database of Slovakia.Travel (2016) used by Kasagranda (2016) or Jurčišinová (2016) was used to identify wellness resorts. The spa and wellness tourist resorts in Slovakia are identified along with the number of guests in these resorts. This article, however, has some constraints that are caused by the absence of data of spa and wellness facilities at the local level (level of individual resorts). Due to this, the data of SO SR (2016) at the level of resorts are represented by the total tourist resorts data, not separately for each tourist spa facility. The authors were provided with the data for the year of 2013 from the database of SO SR (2015) for the quantification of the resorts. For the purposes of quantification, spatial and functional differentiation, and typification, a database of 23 tourism spa resorts (29 spa places) and 29 wellness resorts in Slovakia was processed. The individual spa resorts were differentiated according to the characteristics, resp. specialization, in the sense of the indication groups (what kinds of diseases are treated in the resorts). Furthermore, the numbers and categories of bed capacities, the regeneration lines' performance, and the overall infrastructure of individual baths were taken into account. The infrastructure was subsequently valorised by visitation rate of the facilities and regeneration lines. This valorisation of the individual properties of the resorts was the basis for typization into four significant categories. The resorts of international, national, regional, and local importance were identified. Spa resorts in Vysoké Tatry are specific. There are seven spa locations. These locations were processed separately for cartographic purposes (Figure 6), but in the list of spa resorts (Appendix 
1), the Vysoké Tatry resort is evaluated as one spa resort. In the case of wellness resorts, the infrastructure of the facilities is identified and compared (most importantly wellness lines, which are represented mainly by water parks and other facilities used for similar recreational purposes). The wellness resorts were then valorised and divided into four groups according to their importance (centres with excellent, very good, good facilities and others). The cartographic focus is concentrated on the infrastructure of the recreation line within the resort. The authors do not focus on the number of accommodation facilities or the number of guests due to the previously mentioned problems with the definition of the concept of wellness. Besides the definition problem, these types of tourist resorts are also strongly connected to the resorts of summer recreation by the water. The resulting functional-spatial typology is methodologically processed for the needs of comparisons of spa tourism and wellness centres in the V4 countries.

\section{Results}

\section{A Brief Development and the Importance of Spas, Spa and Wellness Tourism}

The development of spa in Slovakia was influenced mainly by suitable natural conditions. There is no doubt that many mineral and especially thermal springs have been known and used by the local population since the earliest times (e.g. numerous findings from Gánovce). The spa culture in the present form was probably brought to the territory of Slovakia by the Romans at the beginning of the first millennia. During their presence, the Roman cultural and political influence spread to the neighbouring Germanic environment (e.g. the Roman baths in Bratislava-Dúbravka from the $3^{\text {rd }}$ century AD (Šedivý et al., 2012)). During the migration period, upon the arrival of the Slavs, springs (in particular mineral and thermal springs) were undoubtedly one of the objects of worship. This position did not change even after the adoption of Christianity (Masarovičová, 2014). The first written records of mineral and thermal springs in Slovakia date back to the $13^{\text {th }}$ century (in 1247 references of springs in Bardejov and Trenčianske Teplice). This is also related to a considerable universal increase of the number of written references about settlements and localities in the territory of Slovakia (only $12 \%$ of the present municipalities were referenced by the end of the $12^{\text {th }}$ century, but it was more than $40 \%$ by the end of the $13^{\text {th }}$ century (Gurňák, Križan, \& Lauko, 2008)). The first reference of the springs in Turčianske Teplice comes from 1281. In 1402, the spring is already referenced as Thermae Thurocienses - Turčianske kúpele (Fialová \& Orosz, 2012).

However, the most significant development of spa in the territory of Upper Hungary dates back to the period of early modern history, when spa comes to the attention of the nobility and the educated. Descriptions of mineral springs from this period are notorious, especially Werhner's writings: De admirandis Hungariae aquis hypomnemation (Report on the Admirable Waters in Hungary) from 1549. There are many descriptions of localities of today's spa resorts, as well as localities long lost or disappeared (Fialová \& Orosz, 2012). The healing effects of the individual springs are referenced in several other papers and descriptions, even in poetry - e.g. the poem by Adam Trajan Saluberrimae Pistinienses 
Thermae (Healing Spas of Pieštany) from 1642. The period of the Enlightenment in the $18^{\text {th }}$ century commenced the scientific interest in balneotherapy in general as well as in Hungary (e.g. Torkoš (1745) in Schediasma de Thermis Postheinsibus analysed the composition and the effect of mineral water in Pieštany). There were 33 spa sites registered in Slovakia in 1792 (Fialová \& Orosz, 2012). The first permanent buildings were built in some spa resorts at the end of the $18^{\text {th }}$ century (Pieštany after 1772, Bardejov in 1777).

The spas began to be established dominantly by the nobility who owned the land with the mineral springs. Despite the significant development, the spas in Slovakia lagged behind the spas in Western Europe, Germany or Bohemia. Although several spa resorts were visited by prominent guests, they did not, however, exceed the local or national significance. The spas that were among the prominent were Trenčianske Teplice (from 1835 they were transferred to the family of Sinovec from Vienna), Bardejov and Pieštany. The significant development of the spa began in the second half of the $19^{\text {th }}$ century, which was accompanied by a significant increase in the number of bath and spa sites (Masarovičová, 2015). Even some of the Upper-Hungary spas became seasonal centres of social life or relaxation in a pleasant environment. The suburban baths started to gain popularity among the middle class population of the cities. That is why their number rose steadily. Prior to the First World War, the number of spa sites in Slovakia reached 71 (Fialová \& Orosz, 2012). The quality and the infrastructure of most spas were sufficient only for local clients. The systematic construction of spa accommodation establishments and infrastructure began in the mountains at the turn of the $19^{\text {th }}$ and $20^{\text {th }}$ century (especially in Vysoké Tatry). The narrow-gauge railways connected Korytnica spa and Trenčianske Teplice to the railway network in the years of 1908 - 1909 (Kršák et al., 2009).

The First World War and the subsequent creation of Czechoslovakia brought a significant breakthrough in the development of spa industry in Slovakia. It meant a significant drop of living standards of the population and the associated reduction of demand of spa services. In addition, a considerable part of the accommodation capacity was occupied by the military. Part of the spa resorts in eastern Slovakia (Bardejov, Cígel'ka) was also affected by direct war damage during the 1914-1915 war offensives. The integration of Slovakia into Czechoslovakia and the separation from Hungary meant a significant intervention into the development of spa in Slovakia. The Hungarian nobility, the landowners, and the highest class of townsmen had been the most important and most solvent clients of the baths before the war. After the creation of borders, these guests lost interest in visiting the Slovak spa resorts. Many important spa owners were among these groups of people. Gradually, they lost interest in the development of the baths due to political uncertainty. The less developed spas in Slovakia were exposed to a strong competition within Czechoslovakia from the more developed Czech and Moravian spas. In spite of these facts, the quantitative growth of spas in Slovakia culminated in the interwar period of Czechoslovakia. The total number of baths in 1920 was 91. In 1935 the number dropped to 75. Certain spa resorts had experienced a significant development and had become an important monument of modern (predominantly functionalist) architecture, e.g. Pieštany, Sliač. These resorts even gained an air connection during the interwar period (Kršák et al., 2009). 
The Second World War did not help the development of spa in Slovakia. The growing position of state was manifested in both the social and health sectors. The spirit of totalitarian ideology was reflected in the efforts to build (partly following the example of Germany) sanatoriums with massive capacity and healing houses. A large portion of accommodation and medical capacities of spa facilities were used for the needs of the military. A significant part of the spa infrastructure was subsequently damaged or completely destroyed. During the post-war period of reconstruction, fundamental social and economic changes occurred. These changes radically changed the quantitative and qualitative parameters of Slovak spa. The traditional picture of spa life as a leisure time and a way of social and cultural enjoyment was for communists ideologically unacceptable. With the rise of state centralization, regulated economy, state-owned health and social services a significant reduction of the spa network took place. The expert base for this reduction were the conclusions of the fourth balneology conference in 1947, which proposed a methodical classification of Slovak baths into three categories (depending on the chemical properties of mineral waters, their efficiency and the equipment of the spa facilities). Based on the follow-up measures, nationalization and centralization of spa management, the number of spa sites in Slovakia were reduced to 20 by 1951 (Fialová \& Orosz, 2012). Similar rationalization trends in health care sector especially aimed at strengthening of healthcare functions of the resorts were common in other countries even outside of the Communist bloc. That was associated with the further developmental of balneotherapy as a recognized treatment method in the broadest professional circles as well as with the changes in the system of health security (Masarovičová, 2015). The period of stagnation in the 1950s was replaced by a slow development of modern spa after 1960. This was mainly due to the change in the economic priorities of the Communist government, which began to focus more on raising the social and economic levels of the general population. The selected spa resorts with a sufficient potential for mineral and thermal waters had their accommodation and treatment capacities extended. Thanks to the efforts of the centrally managed state economy to expand the possibilities of foreign exchange revenues, the modernization or reconstruction of some spa facilities intended for more solvent foreign clients (e.g. Pieštany) was supported. Several baths started to host again (at least seasonally) significant cultural and social events. In addition to spa, mass recreation has been developing since the late 1960's.

The last significant change of the Slovak spa was the economic transformation of spa in the changed political and social conditions after 1990. The Slovak spas represented a lucrative part of the state property and therefore the privatization of most of the spas took place in the period of 1995-1997, during the controversial period of Mečiar's government (there were some publicized cases connected with the privatization of some baths). These problems complicated the process of transformation of the Slovak spa. Eventually, the ownership as well as the financial management of spas were stabilized. This allowed the inflow of investments into the reconstruction and modernization of the infrastructure of the Slovak spas and their entry into the liberalized spa market. In addition to the spa stays covered by healthcare security, spa facilities started to focus on free tourism in the form of wellness. However, in the second part of the $20^{\text {th }}$ century, 
the development of the spa industry in Slovakia became stabilized (Matlovičová et al., 2013). According to Kulla (2011), the typical spa client has changed significantly over the last 5 years. The number of self-paying guests has increased. This new client has higher accommodation demands and requires shorter than two- or three-week stays. This guest also begins to realize the importance of investing in his/her own health and put more emphasis on the quality / cost ratio. Thus, the spas diverged from their original role of treating patients with specific diseases and started to focus mainly on recreation and leisure with shorter stays.

The development of the thermal swimming pools from the period of socialism was followed by the massive investments that led to the booming development of aquaparks. The aquaparks have become a new and very dynamic factor of the development of tourism (Thermal Park Bešeňová, was opened in 1993 and was expanded between 20062008, the biggest aquapark Tatralandia was opened in 2003 and it is the largest aquapark in Central Europe; in 2004 the Thermalpark - Thermalcorvinus in Vel'ký Meder was opened after the extensive reconstruction and expansion; similarly, the Vadaš thermal bath in Štúrovo was expanded and reconstructed; in 2005 Meander Park was opened in Oravice; followed by an example of the connection of a traditional spa center and an aquapark in Turčianske Teplice in 2006). A typical feature of these aquaparks is that they use thermal water that allows them all-year-round operation. In combination with other tourist attractions in their area (mountain tourism and winter sports), it boosts the visitor potential of the aquaparks, especially in the mountain areas of northern and central Slovakia. Similarly to the neighbouring countries, the Slovak aquaparks have become one of the most popular tourist attractions (e.g. Bešeňová and Tatralandia aquaparks as tourist resorts, each with 200 to 500 thousand guests/visitors per year). Wellness tourism in Slovakia overtook the traditional spa tourism in quantitative indicators (the total number of guests/visitors in spa is only about 200-250 thousand guests/visitors per year) at the beginning of the 21st century. This fact can be considered as another milestone in the development of spa and wellness tourism in Slovakia.

\section{Primary (Natural) Resources and Potential for the Development of the Spas, Spa and Wellness Tourism}

Slovakia is situated in a geologically varied and tectonically complicated area of the Western Carpathians and the northern edges of the Pannonia Basin. It is precisely this geological structure that creates suitable conditions for the relatively frequent occurrence of mineral and thermal waters. These sources have always been one of the main localization assumptions of the development of spa. According to Dubcová et al. (2008), there are 1,657 mineral water resources situated in the area of most geomorphological units in Slovakia. Numerous mineral springs are found mainly in the flysch zone of the Western Carpathians. Most of these springs, known as acidulates, have had only local importance. There are few exceptions. One exception is the Bromo-iron alkaline spring in the spa resort of Bardejov that has been known and has been used since the Middle 
Ages. Other examples are the Nimnica spa resort, and the spring in Cígel'ka and Sulinka. The limit of their use, similarly to the number of other springs in the flysch band, is their relatively low yield. The mineral water is also found in the barley zone, but again due to its geological and tectonic structure, as well as its small size, its occurrence is limited and has only local significance (Lauko, 1997). Due to the favourable geological and tectonic structure, as well as according to the hydrogeological ratio, the Central Carpathian Zone has the best prerequisites for the occurrence of mineral waters. This zone has high occurrence of limestone (nuclear horizons) with rich occurrence of mineral springs (local acids) of local, national or international importance (Strážovské vrchy, Považský Inovec, Vel'ká Fatra and Nízke Tatry). The mountain areas are mostly infiltration areas. The mineral waters are often found in the neighboring basins (Lúčky, Liptovský Ján in Liptovská kotlina, Turčianske Teplice, Budiš in Turčianska kotlina). The most yielding mineral spring in Slovakia is in Vyšné Ružbachy $(1001 /$ s) in Popradská kotlina. Vyšné Ružbachy has its infiltration area approx. in $20 \mathrm{~km}$ distant Belianske Tatry - the limestone part of the Tatras (Lauko, 1997). Part of these mineral springs are also thermal, the most famous of which are the springs in Pieštany $\left(70^{\circ} \mathrm{C}\right)$, Trenčianske Teplice $\left(40^{\circ} \mathrm{C}\right)$ and Rajecké Teplice $\left(38^{\circ} \mathrm{C}\right)$. Similarly, in Slovenské stredohorie the mineral springs are concentrated in the basins, especially in Zvolenska kotlina (Sliač, Kováčová). The important sources of the mineral waters, which are situated directly in the mountain range of Štiavnické vrchy (Vyhne, Sklené Teplice), have their origin in the neo-vulcanic rocks. In the area of Juhoslovenská kotlina, the occurrence of the mineral water resources is linked to the tectonic disturbances, but limited by the hydrogeological potential of the adjacent mountains (as in the flysch zone) that limits their yield. One of the most unique mineral springs of this area is the Číž spring with its unique iodine-bromine alkaline water composition. The occurrence of natural resources of the mineral waters in the lowlands is limited by the geological characteristics to their marginal parts. An example is the surrounding area of Levice within the Podunajská nížina (Dudince, Santovka, Slatina). The spring in Smrdáky in Záhorská nížina is unique in Slovakia for its composition of hydrogen sulphide alkaline iodine water of the petroleum type (located only about $10 \mathrm{~km}$ from oil deposits in the vicinity of Gbely). This unique spring originates from the Neogene sediments (Lauko, 1997). The main areas of occurrence of the mineral waters are not the only areas with potential use. The artificial boreholes have a potential for the use of geothermal energy. The total number of 26 geothermal areas were identified in Slovakia (Franko et al., 1995), from which only a small portion is actively used (10 areas, e.g. Komarňanská kryha and central depression of Podunajská panva - Podunajská rovina, Žilinská kotlina, Liptovská kotlina, Bánovce nad Bebravou, Hornonitrianska kotlina, Rimavská kotlina, Humenský hrb). Other perspective areas are not yet used to their full potential (e.g. Záhorská nížina, Dolné Považie, Turčianska kotlina, Hornádska kotlina, Levočské vrchy, Spišsko-šarišské medzihorie, Košická kotlina).

The sources of the mineral and thermal waters are the most important, but not the only primary localization requirements for spa tourism. It is clear from the facts mentioned above that a considerable part of these resources is located in the mountains and at the foothills of the Western Carpathians. The mountain environment naturally 
increases the attractiveness of the spa location. In the case of Slovakia, a significant concentration of the mineral springs is concentrated in the Central Carpathian Mountains. These mountains are attractive for tourists due to their geological, geomorphological, and floristic diversity. In the $19^{\text {th }}$ century a group of spas and spa towns in the territory of Slovakia were established; they were not bound to the mineral and thermal waters, but instead to the cleanness of the atmosphere in the mountainous and alpine environment. The mountain resorts of Vysoké Tatry dominated these kinds of resorts. Apart from these resorts, there is another resort that has been able to maintain unique status and that is the climate spa of Štós situated in the central part of Volovské vrchy. It is clear that the primary sources of spa and wellness tourism in Slovakia still have a potential for further development despite its intensive usage.

\section{Overview of Spa and Wellness Tourist Resorts}

According to the Ministry of Health of Slovakia (2016), there are 29 "spa places" in 23 spa resorts. According to the Association of Slovak Baths "ASK" (2016), there are 31 spa companies associated in its structure. ASK is an organization that has been a member of the European Spa Association "ESPA" based in Brussels since 2000. The association aims to create conditions that contribute to the development of spa tourism, wellness, and activities promoted by the spa resorts. It also defends the interests of its members against the state, state authorities, or third parties. The Association of Slovak Baths also seeks to protect and promote its interests as well as the interests of its members.

The Ministry of Health of SR (2016) defines 27 cities or villages as spa places or spa resorts according to the Regulation of the Slovak Government no. 446/2006: Bardejov, Bojnice, Brusno, Červený Kláštor, Čiž, Dudince, Korytnica, Kováčová, Kunerad, Liptovský Ján, Lučivná, Lúčky, Nimnica, Pieštany, Rajecké Teplice, Turčianske Teplice, Sliač, Smrdáky, Štós Teplice, Vysoké Tatry (within Vysoké Tatry are spa places Horný, Dolný and Nový Smokovec, Štrbské Pleso, Tatranská Kotlina, Tatranská Polianka and Tatranské Matliare) and Vyšné Ružbachy. These spa places are also referred to as spa tourist resorts for the needs of this paper (in this case, the Vysoké Tatry resort is a resort with seven spa places). These 23 spa resorts are divided into 12 groups according to the predominant indicative group. However, such a division is not very appropriate in the context of tourism because some of the resorts are included in ten (Bardejov), nine (Nimnica, Vyšné Ružbachy) or eight (Lúčky, Trenčianske Teplice) indicative groups. The indicative groups were processed for the purposes of this paper as part of the cartographic output (Figure 6 ). This output was used for the typification of the spa resorts of tourism in Slovakia. The highest number of the resorts (17) can be defined as an indicative group of occupational diseases. This indicative group is followed by a locomotor system diseases (16) and non-tuberculous airway diseases (14). On the contrary, skin and dermatological diseases can only be treated in Smrdáky and Trenčianske Teplice. Nový Smokovec (part of Vysoké Tatry), Štós and Vyšné Ružbachy specialize in treatment of mental illnesses.

The wellness resorts are attractive from the perspective of tourism as well. The defini- 
tion of such resorts is more complicated and inconsistent within the scientific community. For the purpose of this paper, the wellness resorts were identified as those which were assigned a special importance by the recently established Slovak Tourism Agency (2015) (or Slovakia.Travel, 2015). A similar database was used in the elaboration of Kasagranda's dissertation (2016). As part of the typification of the wellness resorts, there are 29 facilities (thermal spas or aquaparks) identified in 29 wellness tourist resorts. These tourist resorts are: Bešeňová, Bojnice, Bystričany, Dolná Strehová, Dolný Kubín, Dudince, Dunajská Streda, Galanta, Horné Saliby, Kaluža, Kováčová, Levice, Liptovský Ján, Liptovský Mikuláš, Lúčky, Oravice, Patince, Podhájska, Poprad, Rajec, Rajecké Teplice, Senec, Sládkovičovo, Štúrovo, Turčianske Teplice, Vel'ký Meder, Vrbov, Vyhne, Vyšné Ružbachy. These tourist resorts are spatially differentiated in the cartographic output (Figure 6), which is a part of the typification of spa tourism and wellness resorts. Their distribution is related to the tectonic structure and the occurrence of specific rocks which the thermal waters are dependent on. The best equipped wellness resorts are Liptovský Mikuláš, Poprad, Senec and Oravice, which have all-year-round operations and have the best infrastructure. The resorts of Patince, Vel'ký Meder (at the same time the spa resort of tourism), and Vyšné Ružbachy are especially popular. Other wellness resorts that exceed the regional importance are Dunajská Streda, Galanta (at the time of the preparation of this text the resort was out of operation due to technical reasons), Podhájska, Štúrovo and Turčianske Teplice.

\section{Accommodation Infrastructure, Guests and Visitors of Spa and Wellness Tourist Resorts}

The total bed capacity of the spa resorts in Slovakia was 13,142 beds in 2015 according to SO SR (2016), with an average of 12,238 beds in the past 10 years (Figure 1). The number of rooms in accommodation facilities in Slovakia was relatively balanced in the past (average for 10 years is 6,261 rooms), while there were 6,622 rooms in 2016. The accommodation facilities (according to SO SR (2016) defined as spa and wellness resort facilities) have 131 beds on average. No significant changes have occurred in the structure of accommodation facilities in recent years. The structure of the accommodation infrastructure necessary for the spa tourism has been stabilized in recent years.

The analysis of the background of spa tourist resorts, specifically the development and increase of the number of beds in the associated resorts (or directly in them), would very likely give different results. These numbers are subjected to a different method of registration at the SO SR (2016). An extreme increase in the number of beds in the spa and wellness tourist resorts would be noticeable in these results. According to the methodology and statistics of SO SR (2016), these numbers are not included in the statistics for spa tourism and wellness. Therefore, the absence of a similar database at the level of the resorts themselves does not allow creation of a similar analysis.

When differencing at the level of regions/counties, the regions of Banská Bystrica, Prešov and Žilina have a dominant position. The resorts are concentrated in the above- 
Figure 1 Development of the tourism accommodation facilities in spa resorts in selected years

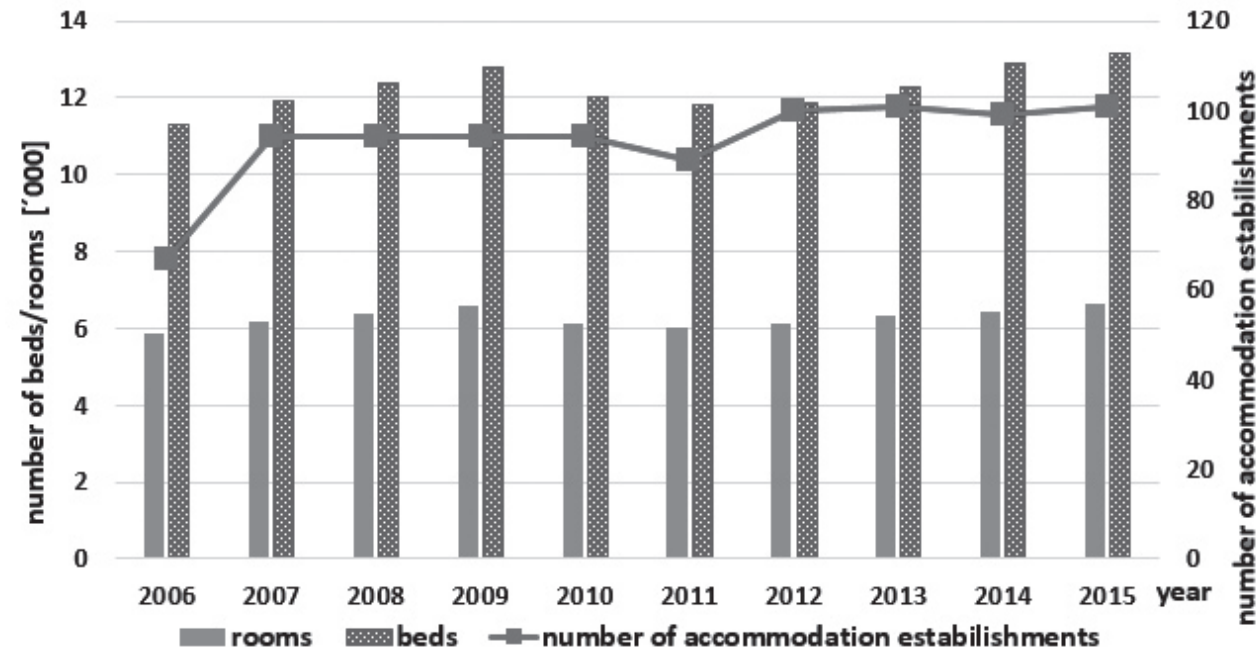

Source: Statistical Office of the Slovak Republic (2016) - authors' own processing

mentioned regions towards Central Slovakia that is extremely suitable for this type of tourism for its natural conditions. On the contrary, the least suitable conditions for spa tourism and wellness are in Bratislava and Košice county/region.

The best equipped and currently most visited resorts are Vysoké Tatry (within the spa resorts Štrbské Pleso and Horný, Dolný and Nový Smokovec), Pieštany, Trenčianske Teplice, Dudince and Bardejov (Table 1). All these are the resorts with a long-standing spa tradition. They are also known in broader European area. According to Vystoupil et al. (2016), Vysoké Tatry and Bardejov have also special importance for other types of tourism such as high mountain recreation in Vysoké Tatry (hiking in summer and skiing and winter sports in winter) and cultural, sightseeing and urban tourism in Bardejov (UNESCO monuments in the town itself). Pieštany, Trenčianske Teplice, and Dudince more or less specialize in the spa industry and according to the functional and spatial context of Vystoupil et al. (2016), these can be clearly defined as the spa tourist resorts.

According to Slovakia.Travel (2015), Lonely Planet ranked Slovakia as the fifth in the "top 10 most interesting countries to visit" in 2013. Pieštany spa are among the TOP 20 spa resorts in Europe. The list of the most successful spa resorts in Slovakia should include resorts of Pieštany, Rajecké Teplice, Bojnice, Bardejov, Dudince, Turčianske Teplice, Vyšné Ružbachy, Lúčky and Nimnica. The visit rate of the Slovak tourist resorts has been analyzed in geographically-focused papers over the past decade. Within these frameworks, authors focused on the spatial identification and valorisation at different hierarchical levels - from national (Kasagranda, 2015a) and regional level (Klamár, 2014) to the papers focused on individual resorts in case studies at the local level (e.g. Kulla \& Nedvid'ová, 2014; Kulla, 2007). 
Table 1 Spa resorts in Slovakia and its specifications in $2013^{\star \star}$

\begin{tabular}{|c|c|c|c|c|c|c|}
\hline $\begin{array}{l}\frac{1}{0} \\
0 \\
0 \\
0 \\
0 \\
0\end{array}$ & 文 & $\begin{array}{l}{ }^{*} \\
\text { 옹 } \\
\mathbb{\infty}\end{array}$ & 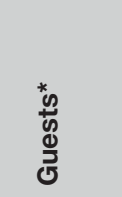 & 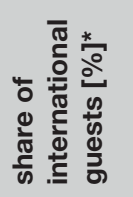 & 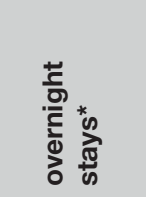 & 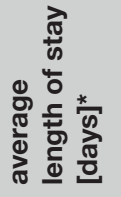 \\
\hline Vysoké Tatry & Prešov & 7,092 & 214,839 & 34.05 & 756,051 & 3.5 \\
\hline Piešt'any & Trnava & 4,218 & 88,846 & 46.30 & 576,803 & 6.5 \\
\hline Trenčianske Teplice & Trenčín & 1,885 & 48,497 & 25.55 & 309,345 & 6.4 \\
\hline Dudince & Banská Bystrica & 1,697 & 54,326 & 16.03 & 310,963 & 5.7 \\
\hline Bardejov & Prešov & 1,876 & 38,944 & 20.52 & 263,249 & 6.8 \\
\hline Bojnice & Trenčín & 1,940 & 31,393 & 27.59 & 233,172 & 7.4 \\
\hline Turčianske Teplice & Žilina & 1,164 & 27,225 & 18.40 & 223,831 & 8.2 \\
\hline Liptovský Ján & Žilina & 1,851 & 51,527 & 16.67 & 180,847 & 3.5 \\
\hline Rajecké Teplice & Žilina & 1,046 & 39,966 & 41.66 & 139,573 & 3.5 \\
\hline Lúčky & Žilina & 439 & 10,974 & 20.04 & 101,676 & 9.3 \\
\hline Kováčová & Banská Bystrica & 497 & 8,752 & 0.55 & 104,195 & 11.9 \\
\hline Vyšné Ružbachy & Prešov & 944 & 16,375 & 23.62 & 86,904 & 5.3 \\
\hline Sliač & Banská Bystrica & 684 & 16,707 & 15.51 & 86,831 & 5.2 \\
\hline Nimnica & Trenčín & 339 & 10,299 & 4.63 & 79,198 & 7.7 \\
\hline Smrdáky & Trnava & 315 & 3,867 & 14.48 & 72,242 & 18.7 \\
\hline Štós & Košice & 262 & 1,413 & 0.00 & 13,674 & 9.7 \\
\hline Sklené Teplice & Banská Bystrica & 354 & 5,984 & 13.65 & 47,481 & 7.9 \\
\hline Číž & Banská Bystrica & 309 & 5,627 & 3.04 & 44,896 & 8.0 \\
\hline Lučivná & Prešov & 270 & 6,560 & 1.11 & 67,076 & 10.2 \\
\hline Brusno & Banská Bystrica & $x x^{\star \star \star}$ & 8,056 & 8.32 & 56,829 & 7.1 \\
\hline Červený Kláštor & Prešov & 329 & 6,597 & 20.69 & 20,404 & 3.1 \\
\hline TOTAL**** & - & 27,511 & 696,774 & $28.0 \%$ & $3,775,240$ & 5.4 \\
\hline
\end{tabular}

* data of beds, guests, overnight stays and etc. includes values for whole resorts - in many cases not only for spa tourism establishments; therefore they are not $100 \%$ consistent with other database used in this paper

** Due to the absence of a database at the level of resorts itself for 2015 are used data for 2013

*** Private information based on methodology of Staistical Office of Slovak Republic

${ }^{* * \star *}$ Kunerad a Korytnica were not includet in database from SO SR (2015); therefore numbers of beds, guests and etc. were not evaluated

Source: Statistical Office of the Slovak Republic (2015) - authors' own processing 
In the monitored ten-year period (2006-2015), 271,538 guests/tourists visited the spa and wellness resorts on average per year (Slovak tourists' form $72.9 \%$ and international tourists $37.2 \%$ of total share (Table 2)). Most of the guests came to the resorts in 2015 (304,975 guests) and 2014 (299,032 guests). The average length of stay is on average 9.2 days, with longer stays done by Slovak guests (9.4 days) than by the foreign guests (8.5 days).

From the perspective of the quantitative analysis and the share of the visit rate of the spa and wellness tourist resorts in the structure of tourism in Slovakia, the most interesting figure is the number of guests/tourist and the share of the overnight stays in the resorts (Figure 2). The average number of the overnights stays during the period of 2006-2015 is 2,478,966.5 (out of which $74.7 \%$ were the Slovak and $25.3 \%$ of foreign guests) with a maximum in 2015 (with a total of 2,612,785 overnight stays). It is characteristic for this type of tourism to have a high number of the overnight stays and a higher average length of stay with values over three days. This high average length of stay is not typical of any other type of Slovak tourism. It also constitutes an important share of the total visit rate of Slovak tourism.

Figure 2 Development of the tourism performance in spa resorts in selected years

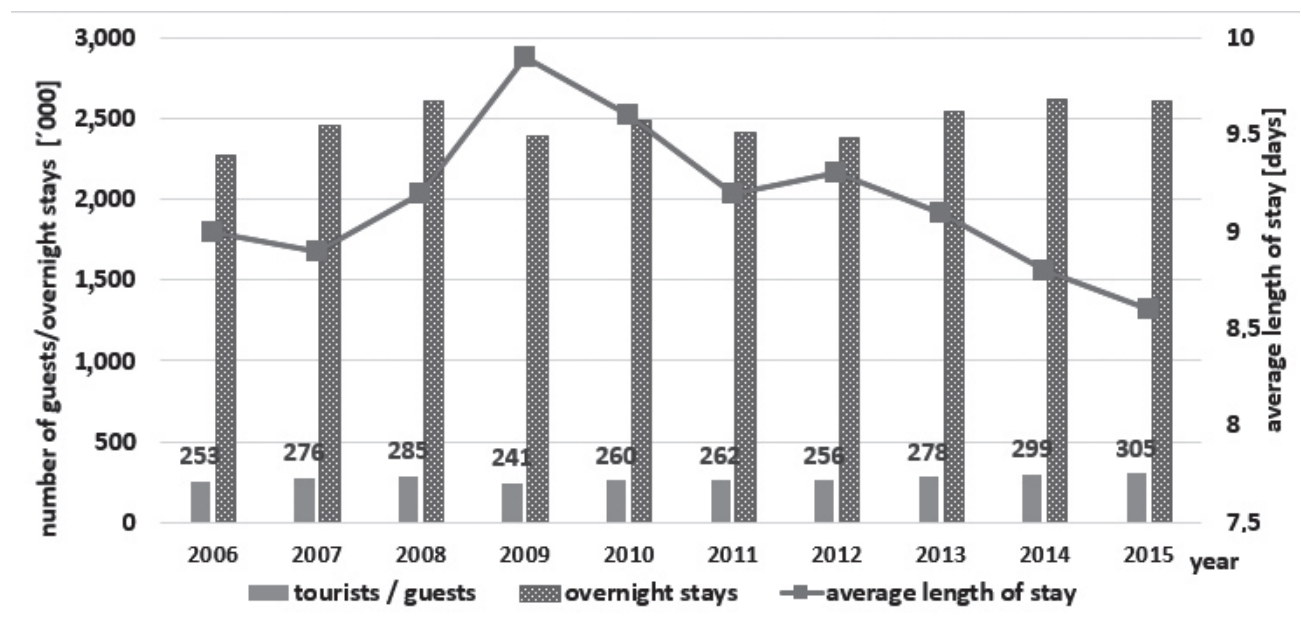

Source: Statistical Office of the Slovak Republic (2016) - authors' own processing

In the ten-year period of 2006-2015, spa and wellness tourism made up on average a share of $7.3 \%$ of the total visit rate of tourism and up to $22.3 \%$ of the total share of the overnight stays (Figure 2, Appendix 1). In particular, the figure of the proportion of the overnight stays unambiguously confirms the high importance of spa and wellness tourism within the internal typology of Slovak tourism.

Several authors pay attention to the structure of international guests/tourists in the tourist resorts in Slovakia (Bučeková et al., 2016; Kasagranda, 2015b; Kulla \& Nedvid’ová, 
2014, and others). According to the discussions of these authors, many tourists come to Slovakia because of spa and wellness tourism. The largest share of the tourist visit rate was formed by the tourists from Czechia (43.6\%), Germany (12.2\%), Israel (9.3\%), and Russia (5.2\%) (Figure 3 and 4; Table 2). A dramatic decrease in the number of international tourists was recorded between the years of 2008 and 2009 (from 92,755 to 60,326 tourists; decrease of $35 \%$ ) and in the number of the overnight stays as well (from 791,233 to 549,828 ; decrease of $31 \%$ ). This situation was caused by the impact of the economic crisis which affected the whole Slovak tourism industry. After 2009 the number of international tourists relatively stabilized (at approximately 65,000 international tourists) with a constant average length of stay between 8 to 9 days.

Figure 3 Structure of guests/tourists in spa tourism of Slovakia in 2015

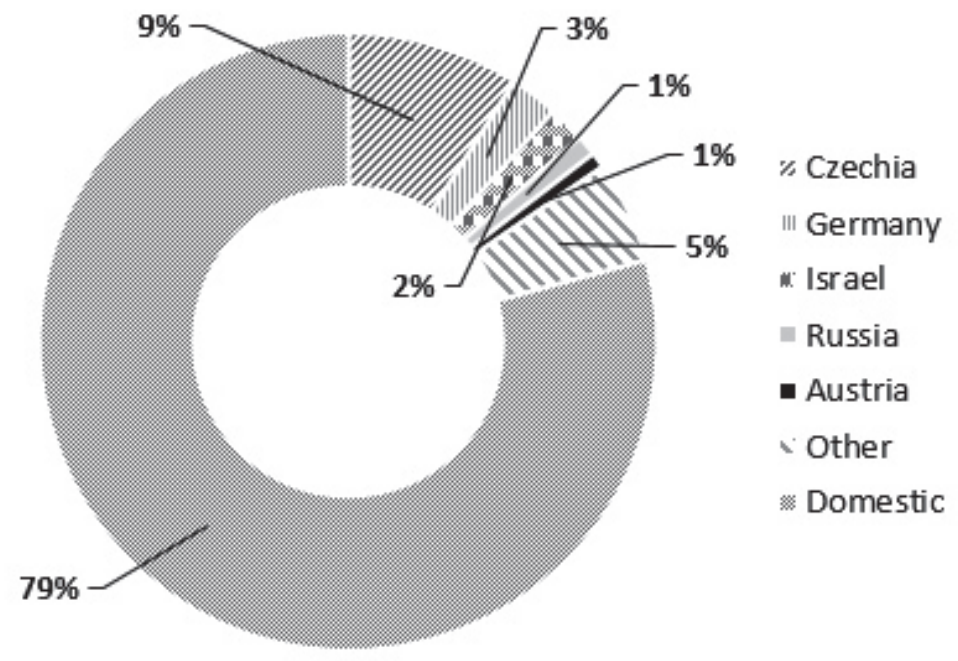

Source: Statistical Office of the Slovak Republic (2016) - authors' own processing

Very high percentage of lucrative international tourists/guests in the most important tourist resorts is typical of this type of tourism. Due to the considerably was recorded higher average length of stay of tourists from Germany and Israel (both 13.9 days). In the comparison average length of stay of the tourists from Czechia is 4.7 days (Figures 3 \& 4; Table 2). On the other hand, the number of the overnight stays by tourists from these three countries is fairly balanced $(25.8 \%$ of the total share of overnight stay for Czech, 21.2\% for German and 16.2\% of Israeli tourists). The structure, the share of international tourists/guests, and the length of their stay indicate that tourists from Czechia probably conduct shorter visits or their main holiday takes place in other destinations or they make only a few shorter trips to Slovakia. 
Figure 4 Structure of foreign guests/tourists in spa tourism of Slovakia in 2015

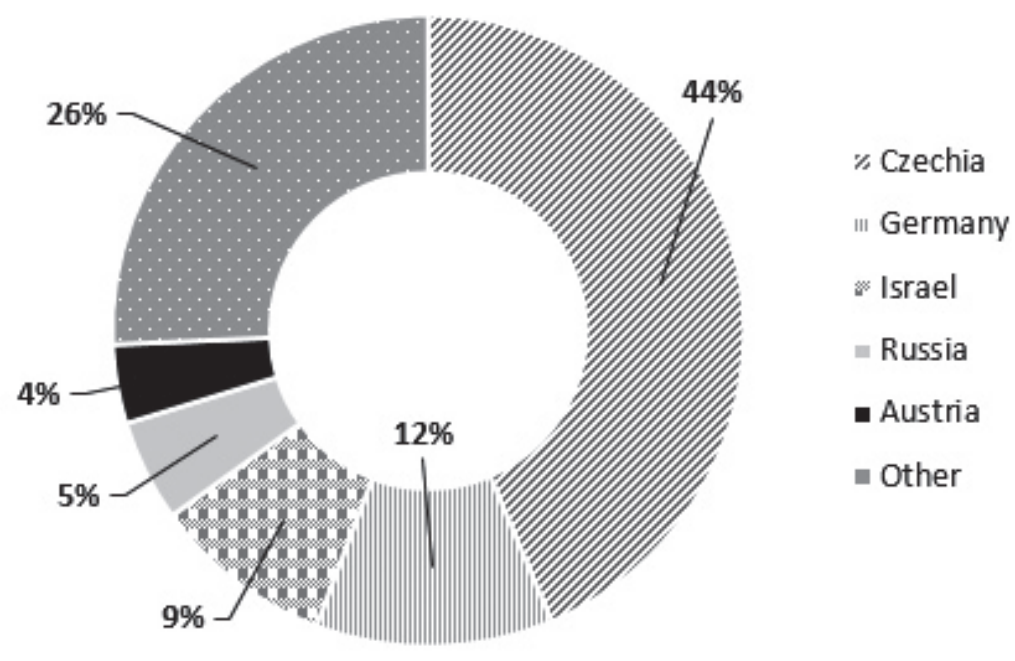

Source: Statistical Office of the Slovak Republic (2016) - authors' own processing

Table 2: Structure of guests/tourists (domestic and main international) in spa resorts of Slovakia in 2015

\begin{tabular}{|c|c|c|c|c|c|c|c|c|c|}
\hline \multirow{4}{*}{$\begin{array}{l}\text { country } \\
\text { of origin }\end{array}$} & \multicolumn{4}{|c|}{ guests / tourists } & \multicolumn{4}{|c|}{ overnight stays } & \multirow{3}{*}{$\begin{array}{c}\text { average } \\
\text { length of } \\
\text { stay }\end{array}$} \\
\hline & \multirow{3}{*}{$\begin{array}{c}\text { number } \\
\text { of guests } \\
\text { ['000] }\end{array}$} & \multicolumn{2}{|c|}{ share } & \multirow{2}{*}{ index } & \multirow{3}{*}{$\begin{array}{c}\text { number } \\
\text { of stays } \\
\text { ['000] }\end{array}$} & \multicolumn{2}{|c|}{ share } & \multirow{2}{*}{ index } & \\
\hline & & internat. & total & & & internat. & total & & \\
\hline & & [\%] & {$[\%]$} & [\%] & & [\%] & [\%] & [\%] & days \\
\hline Czechia & 27.60 & 43.6 & 9.1 & 101 & 130.30 & 25.8 & 5.0 & 100.1 & 4.7 \\
\hline Germany & 7.70 & 12.2 & 2.5 & 72.3 & 107.03 & 21.2 & 4.1 & 80.6 & 13.9 \\
\hline Israel & 5.87 & 9.3 & 1.9 & 107.8 & 81.61 & 16.2 & 3.1 & 108.2 & 13.9 \\
\hline Russia & 3.30 & 5.2 & 1.1 & 60.7 & 39.93 & 7.9 & 1.5 & 66.8 & 12.1 \\
\hline Austria & 2.56 & 4.0 & 0.8 & 93.2 & 19.73 & 3.9 & 0.8 & 91.0 & 7.7 \\
\hline Other & 16.26 & 25.7 & 5.3 & 95.1 & 126.27 & 25.0 & 4.8 & 97.3 & 9.7 \\
\hline Domestic & 241.70 & - & 79.3 & 104.9 & $2,107.91$ & - & 80.7 & 102.0 & 8.7 \\
\hline TOTAL & 304.98 & - & - & 102 & $2,612.79$ & - & - & 99.8 & 8.6 \\
\hline
\end{tabular}

Source: Statistical Office of the Slovak Republic (2016) - authors' own processing 
Spa and wellness tourism creates a significant part of the total revenues (Figure 5) in tourism. In the monitored period (2006-2015), spa tourism had revenues with the average value of 49.96 million. $€$ (maximum of 57.86 million $€$ in 2014; minimum of 38.57 million $€$ in 2006), with a significantly higher share of revenues from domestic tourism $(65.82 \%)$ than from foreign tourism $(34.18 \%)$ (even in the number of tourists and overnight stays). The total share of the spa and wellness accommodation revenues from the tourism accommodation establishments in the tourist resorts has been over $15 \%$ for a longer period of time. In the monitored period (2006-2015), the share was on average $19.23 \%$ (with a maximum of $21.9 \%$ in 2010 ; respectively $21.6 \%$ in 2014 ). This type of tourism represents $1 / 5$ of the total share of the tourism revenue in general.

Figure 5 Development of the revenues of spa tourism in selected years

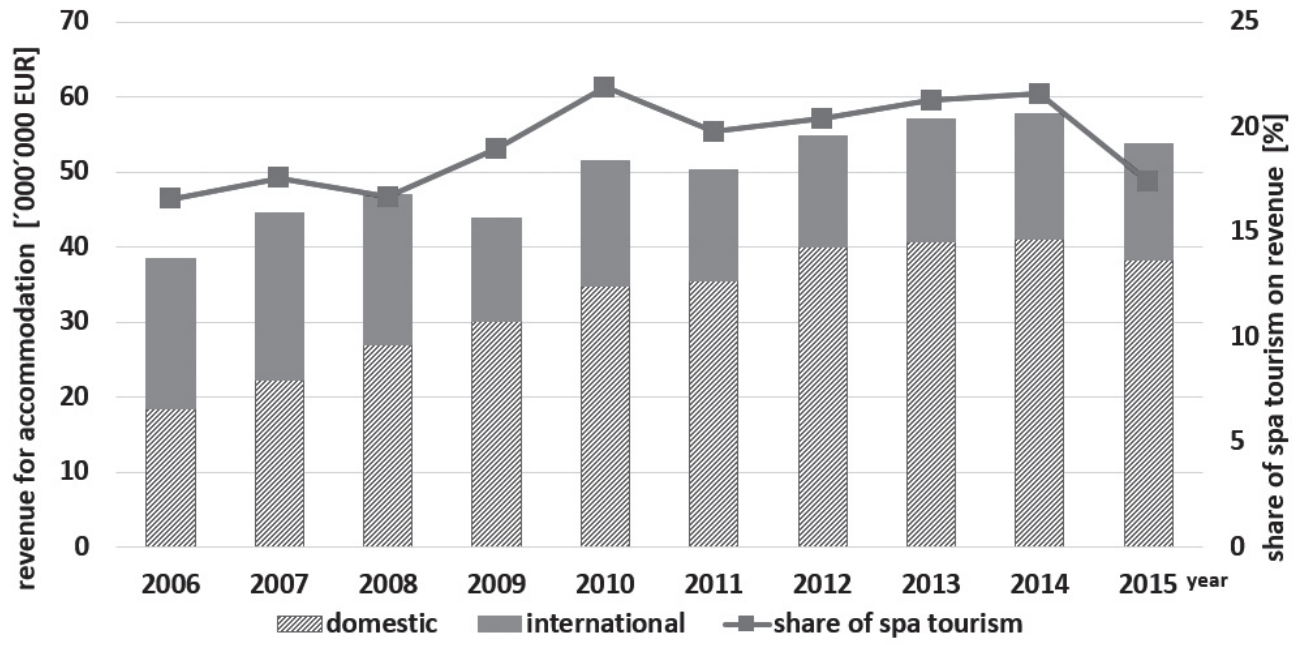

Source: Statistical Office of the Slovak Republic (2016) - authors' own processing

\section{Functionally-Spatial Typology of Spa and Wellness Tourist Resorts}

The typification of the tourist resorts has been discussed in papers by Slovak geographers over the past decade. The most appealing are the studies by Kasagranda et al. (2016), Klamár \& Kolesárová (2015), Plesník (2008), Vystoupil et al. (2016), or Weiss et al. (2005).

The spa resorts were divided into four categories according to the importance for tourism. There were several criteria measured: priority beds - their number and structure, the capacity of congress and conference rooms, quality and quantity of the offered services (including sport and leisure activities, equipment in categories such as cycling, crosscountry skiing, tennis, golf, minigolf, or wellness activity), visit rate of resorts (number of tourists, overnight stays and average stay) and equipment of the regeneration lines of the 
resorts themselves. The last criterions were traditions, history and the share of international tourists and their consequent valorisation of the importance from the perspective of the Ministry of Health SR (2016).

Table 3 Categorization of spa resorts according to their importance for spa tourism

\begin{tabular}{|c|c|c|}
\hline Improtance & Spa Resort & Basic Characteristics \\
\hline International & $\begin{array}{l}\text { Pieštáany, Bardejov, } \\
\text { Vysoké Tatry }\end{array}$ & $\begin{array}{l}\text { - high price and share of } 4 \text { * accommodation facilities } \\
\text { - high capacity for congresses and conferences } \\
\text { - high quality and quantity of offered services } \\
\text { - a long tradition }\end{array}$ \\
\hline National & $\begin{array}{l}\text { Bojnice, Štrbské pleso, Sliač, } \\
\text { Dudince, Trenčianske Teplice, } \\
\text { Turčianske Teplice, Rajecké } \\
\text { Teplice }\end{array}$ & $\begin{array}{l}\text { - medium high price per bed } \\
-3{ }^{*} \text { and } 4{ }^{*} \text { accommodation facilities } \\
\text { - relatively high capacity for congresses and } \\
\text { conferences } \\
\text { - medium quality and quantity of services offered } \\
\text { - a relativly long tradition }\end{array}$ \\
\hline Regional & $\begin{array}{l}\text { Vyšné Ružbachy, Nimnica, Nový } \\
\text { Smokovec, Sklené Teplice, Brusno }\end{array}$ & $\begin{array}{l}\text { - medium high price per bed } \\
\text { - mostly } 3^{*} \text { accommodation facilities } \\
\text { - medium capacity for congresses and conferences } \\
\text { - average quality and quantity of offered services } \\
\text { - a shorter tradition }\end{array}$ \\
\hline Local & $\begin{array}{l}\text { Liptovský Ján, Horný Smokovec, } \\
\text { Lučivá, Číž, Štós, Smrdáky, } \\
\text { Dolný Smokovec, Tatranské } \\
\text { Matliare, Tatranská Polianka, } \\
\text { Tatranská Kotlina, Červený kláštor, } \\
\text { Kováčová, Lúčky }\end{array}$ & $\begin{array}{l}\text { - low price per bed } \\
\text { - mostly } 2^{*} \text {, resp. } 3^{*} \text { accommodation facilities } \\
\text { - low capacity for congresses and conferences } \\
\text { - low quality and quantity of services offered }\end{array}$ \\
\hline
\end{tabular}

* Vysoké Tatry are evaluated twice (once as a whole tourism resort; secondly as 7 spa places based on MZ(H) SR; 2016)

Source: authors' own processing; based on methodology of Kasagranda (2016), Vystoupil, Šauer et al. (2011), precisley Zelenáková (2014)

Pieštany and Bardejov were identified as the resorts with international importance in Slovakia (Table 3; Figure 6). If Vysoké Tatry is identified as one resort (with seven spa places), then three spas of international importance could be identified. These resorts have the best infrastructure (material, technical) and at the same time, they are the most visited spa resorts (with a high proportion of international tourists). Pieštany and Bardejov are the resorts with an extraordinary spa tradition which exceeds the national significance. This fact is supported by the high share of international tourists, especially in Pieštany. The attractiveness of Bardejov is increased by the presence of the UNESCO monument (historical city centre with the town hall and the Basilica of St. Egidius). However, this attractiveness cannot be compared with the spas since the spas have equally extraordinary significance on their own. 


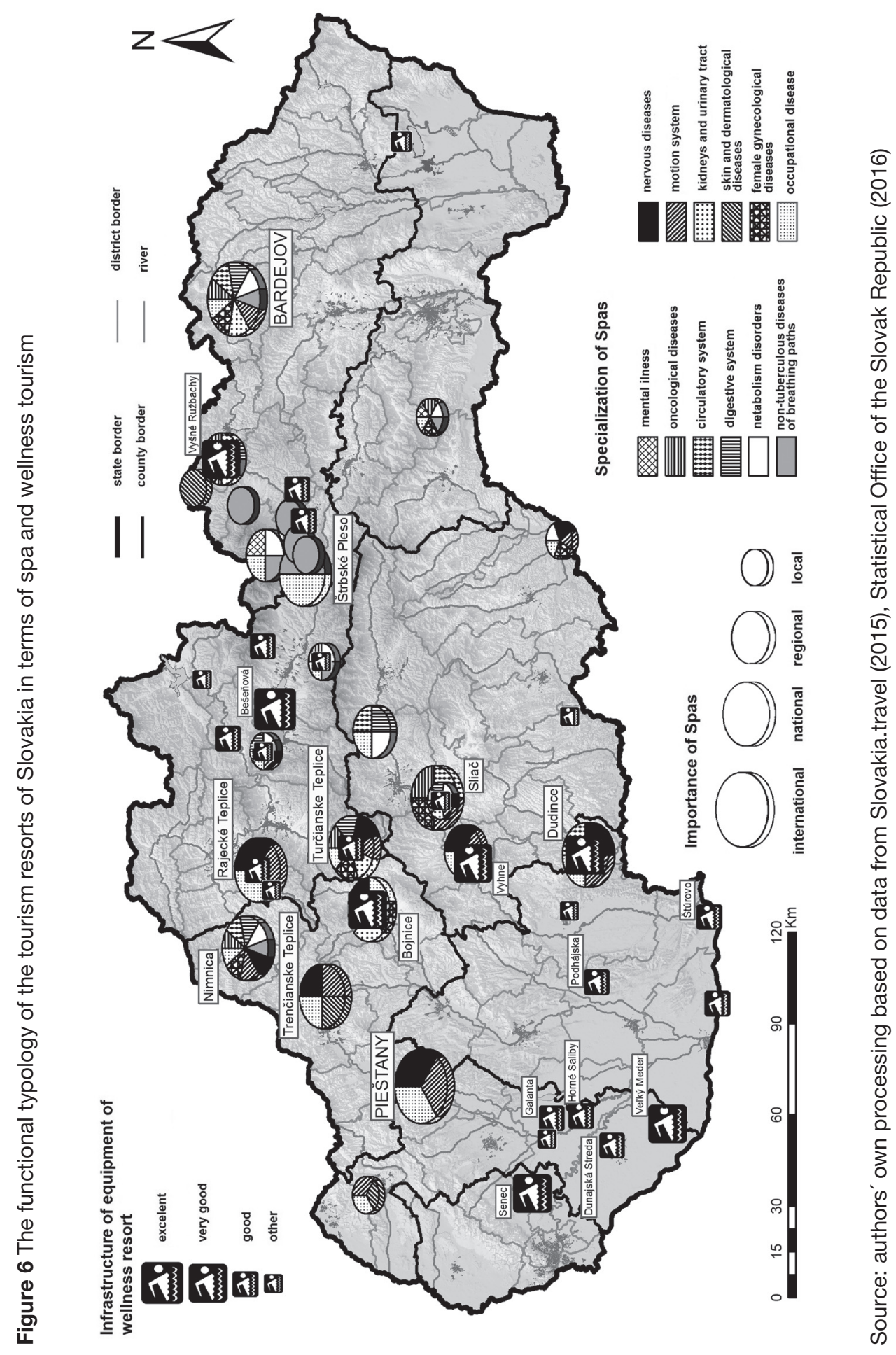


There are six spa resorts with national importance (if Vysoké Tatry is taken as one resort) (Figure 6; Table 3). These resorts are: Bojnice, Sliač, Dudince, Trenčianske Teplice, Turčianske Teplice, Rajecké Teplice (partially Štrbské Pleso as a part of Vysoké Tatry). These resorts have a high share of international tourists (25.6\%), mostly from Czechia (with the exception of Trenčianske and Rajecké Teplice, where many international guests arrive from more distant countries of the Arab world). These are the resorts with excellent infrastructure and a good capacity of regeneration lines. Smaller congresses or conferences can be held there as well.

Four resorts are evaluated as the resorts of regional importance (Figure 6; Table 3), such as Nimnica, Vyšné Ružbachy, Sklene Teplice and Brusno (Horný Smokovec is part of the Vysoké Tatry) with the share of international tourists around 12.6\%. The most important resort with regional importance is Vyšné Ružbachy) with the highest share of international tourists $(23.6 \%)$.

The local importance was assigned to the remaining six spa resorts, such as Liptovský Ján, Lučivná, Číž, Štós, Smrdáky, Červený kláštor, Kováčová and Lúčky (If Horný and Dolný Smokovec, Tatranská Matliare, Tatranska Polianka, Tatranská Kotlina are part of the Vysoké Tatry resort).

Wellness is very popular, in combination with the spa use of the thermal and mineral waters. This is mainly related to the construction of the aquaparks, which were evaluated by Žoncová et al. (2015) or Marčeková et al. (2015).

The characteristics of the wellness resorts ware based on the database from Slovakia. travel.sk (2015). It is important to note that in the cases of the most important wellness resorts, only the infrastructure of its wellness facilities was evaluated, not the whole resort (Figure 6). The wellness resort and its facility in Bešeňová (the best in all indicators, with all-year-round operation) was evaluated as a resort with excellent infrastructure. Bojnice, Dudince, Senec, Vyšné Ružbachy, Vel'ký Meder and Vyhne have very good infrastructure. There are twelve resorts with good infrastructure (Dunajská Streda, Galanta, Horné Saliby, Liptovský Mikuláš, Poprad, Štúrovo, Turčianske Teplice, Vrbov, Dolný Kubín, Patince, Podhájska and Rajecké Teplice). The remaining nine aquaparks (Kováčová, Liptovský Ján, Lúčky, Kaluža, Levice, Oravice, Rajec, Dolná Strehová and Sládkovičovo) are evaluated as others.

Spa and wellness is a very important and internationally attractive type of tourism in present Slovak tourism. They attract many foreign visitors every year and co-create the product of Slovak tourism in a significant way. As it has been mentioned above, with the current pace of the wellness development and building of the aquaparks, one can expect that its position within the structure of tourism will be rising. 


\section{Discusion}

Slovakia is the smallest country from the V4 countries by size, population, and tourism output (volume in millions of EUR, share of GDP, or number of tourists). At the same time, it is the country where international tourists from other countries of the V4 (especially from the Czech Republic) are extremely important for tourism of the country. A significant share of international tourists from the V4 countries in the spa resorts suggests the importance of spa resorts and wellness within V4. The Slovak tourists who participate in spa tourism and wellness prefer the Slovak Spas to the spas in other V4 countries. An important phenomenon in recent years has been the aquaparks. The visit rate of the Slovak aquaparks is significantly influenced by the guests from the V4 countries, mainly from Poland and the Czech Republic.

Slovakia is a country with significant status of spa tourism in its structure. Pieštany, Vysoké Tatry and other resorts have an extraordinary share of international tourists/ guests. The country has the appropriate natural conditions for the development of this type of tourism. Government and non-governmental investment support is clear in its development. Spa and wellness is one of the strategic priorities of the development in the programming statement of the Slovak Council under the "Program of the Development of Slovak tourism" till 2020.

The Slovak spas have gone through significant structural changes. The spas functionality transformed from the original healing-sanitation function to a recreational-leisure function. There was a change in the services offered in the resorts as the result of this transformation, a few of which are the development of the additional infrastructure, the structure of the healing process, the length of the stays themselves (as well as their cost) and the seasonality of the tourist visits or the structure of the guests/ tourists themselves. The important players in the structure of spa and wellness tourism have been the aquaparks in the wellness resorts and others similar regeneration lines in recent years. Their number of guests exceeds the numbers of spa resorts. The aquaparks are often an additional infrastructure in the spa resorts themselves. That is why the spa resorts are becoming resorts of wellness as well.

\section{Conclusion}

Spa tourism and wellness is an important type of tourism in Slovakia. There are many obvious characteristics such as historical significance, very suitable natural conditions/ localization assumptions, well-developed infrastructure in the most important resorts of international importance as well as its considerable share on the overall tourism of Slovakia (primarily in terms of its share in the production of tourism revenue and overnight stays). These characteristics clearly show its importance in the structure of tourism not only in Slovakia but throughout Central Europe. The representatives at national level are aware of the importance of spa and wellness tourism. They categorized it within the programming documentation intended for the development of tourism in Slovakia as one of the main forms (in the sense of authors' listed types) of tourism of Slovakia. 
The spa has a significant share in the tourism in Slovakia, and economic and other benefits as well. Spa and wellness tourism makes $22.28 \%$ share of overall overnight stays but only about $7.26 \%$ share of the overall guests. In terms of revenues, it is also $19.23 \%$ share of the overall tourism revenues. One can only assume that the overall economic benefit of this type of tourism is higher. Spa tourism is mostly made by tourists who relax at the place of residence and are likely to carry out activities related to the consumption of regional products.

The status of spa place in Slovakia is allocated to 29 places, respectively to 23 resorts, out of which three have international importance, with a high share of international tourists. The most important resorts of spa tourism are Pieštany, Bardejov and Vysoké Tatry with international significance and Bojnice, Nimnica, Sliač, Dudince, Trenčianske Teplice, Turčianske Teplice and Rajecké Teplice with national significance. From the wellness point of view, the most important resorts are Bešeňová, Bojnice, Dudince, Senec, Vyšné Ružbachy, Vel'ký Meder and Vyhne.

It is possible to assume that the position of this type of tourism in Slovakia will become more dominant and it will increase its share in the structure of tourism in the future. The importance of spas will grow along with the importance of wellness resorts. The wellness resorts today outmatch (at least in the number of tourists/guests) the traditional spa tourism. It is possible to assume that the share of international tourists will rise as well.

\section{Acknowledgements}

This paper was supported by the grant of VEGA No. 1/0540/16 "Social, economic and environmental determinants of regional development and transformation: a regional geographic approach".

\section{References}

Bučeková, I., Nováková, G., \& Kusendová, D. (2016). Časovo-priestorová diferencie v zahraničnej návštevnosti Slovenska (Time-space differences in foreign tourists' attendance in Slovakia). Geograficý časopis (Geographical Journal), 68(4), 333-351.

Cákoci, R. (2013). Cestovný ruch na Slovensku (Tourism in Slovakia). In V. Lauko (Ed.), Geografia Slovenskej republiky. Humánna geografia (Geography of Slovak Republic. Human Geography) (pp. 214-253). Bratislava, Slovak Republic: Geografika.

Cákoci, R., Kasagranda, A., \& Tolmáči, L. (2014). Cestovný ruch na Slovensku (Tourism in Slovakia). In V. Lauko (Ed.), Regionálne dimenzie Slovenska (Regional Dimensions of Slovakia) (pp. 479498). Bratislava, Slovak Republic: Comenius University in Bratislava.

Čuka, P., \& Šenková, A. (2012). Geography of Tourism of Slovakia. In K. Widawski \& J. Wyrzykowski (Eds.), Geography of Tourism of Central and Eastern Europe Countries (pp. 381-406). Wroclaw, Poland: University of Wroclaw.

Dorocki, S., \& Brzegowy, P. (2014). Ski and spa tourism as local development strategy - the case of Krynica Zdrój (Poland). Annales Universitatis Paedagogicae Cracoviensis Studia Geographica 5. 88 - 116.

Dubcová, A. et al. (2008). Geografia Slovenska (Geography of Slovakia). Nitra, Slovak Republic: Constantine the Philosopher University. 
Dubcová, K. (2014). Porovnanie rozvoja kúpelnítva v Českej republike a na Slovensku (Comparasion of the Development of Spa Industry in Czech Republic and Slovakia). Master Thesis. Prague, Czech Republic: The Institute of Hospitality Management in Prague.

Eliašová, D. (2009). Slovenské kúpelníctvo v 20. storoči (Slovakian spa industry in $20^{\text {th }}$ century). Bratislava, Slovak Republic: EKONÓM.

Eliašová, D. (2015). Potenciál zaniknutých kúpel’ov pre rozvoj cestovného ruchu v SR (Potential of Extinct spas for development of Tourism in Slovakia). In Šperková (Ed.), Cestovni ruch, hotelnictví a gastronomie jako fenomén 21. stoleti. (Tourism, Hotel Industry and gastronomy as a phenomena of $21^{\text {st }}$ century) (pp. 45-52). Brno, Czech Republic: College of Business and Hotel Management.

Eliašová, D. (2016). Destinačný manažment v kúpelných miestach (Destination management in spa towns). In Šperková (Ed.), Nové trendy v cestovním ruchu (New trends in Tourism) (pp. 42-49). Brno, Czech Republic: College of Business and Hotel Management.

Erdeli, G., Dinca, A. I., Gheorghilas, A., \& Surugiu, C. (2011). Romanian Spa Tourism: A Communist Paradigm in a Post-Communist Era. Human Geographies, 5(2), 41-56. DOI: 10.5719/ hgeo.2011.52.41.

Fialová, D., \& Orosz, Ö. (2012). Vývoj lázeňství na území dnešního Slovenska (v období od konce 16. století do Současnosti) (Development of spa industry on territory of current Slovakia (in etape from $16^{\text {th }}$ century to present). Klaudyán: internetový ćasopis pro historickou geografii a environmentální dĕjiny (Klaudyán: internet journal for historical geography and environmental history), 8(2), 94-106.

Franko, O., \& Remšík, A. et al. (1995). Atlas geotermálnej energie Slovenska (Atlas of Geothermal Energy of Slovakia). Bratislava, Slovak Republic: Geologický ústav Dionýza Štúra.

Gúčik, M., Kvasnová, D., \& Pančíková, K. (2016). Medical Spa versus Health Tourism. Acta Academica Karviniensia, 16(2), 5-15.

Gurňák, D., Križan, F., \& Lauko, V. (2008). Časovo-priestorové aspekty vývoja sídelnej siete Slovenska (Spacetime Aspects of Settlement System Development in Slovakia). Geographia Casoviensis, 2(1), 34-37.

Gustavo, N. S. (2010). A 21st-Century Approach to Health Tourism Spas: The Case of Portugal. Journal of Hospitality and Tourism Management, 17(1), 127-135. DOI: 10.1375/jhtm.17.1.127.

Hall, M. (2003). Spa and Health Tourism. In Hudson (ed.), Sport and Adventure Tourism (pp. 273-292). New York/London/Oxford: The Harworth Press.

Jurčišinová, A. (2016). Kúpelnictvo a wellness ako typ cestovného ruchu na Slovensku a jeho priestorové prejary (Spa and wellness as type of tourism in Slovakia and its spatial patterns). Bachalor Thesis. Bratislava, Slovak Republic: Comenius University in Bratislava.

Kasagranda, A. (2015a). Spatial Differentiation and Evaluation of Tourism Performance of Slovakia and Its Specificities. Czech Journal of Tourism, 4(1), 58-74. DOI: 10.1515/cjot-2015-0004.

Kasagranda, A. (2015b). Hodnotenie a priestorová diferenciácia zahraničnej návštevnosti na Slovensku (Evaluation and Spatial Differentiation of Foreign Touristic Attendance of Slovakia). Journal of Tourism, Hospitality, and Commerce, 6(2), 19-32.

Kasagranda, A. (2016). Hodnotenie a priestorová diferenciácia cestovného ruchu na Slovensku (Evaluation and Spatial Differentiation of Tourism in Slovakia). Dissertation Thesis. Bratislava, Slovak Republic: Comenius University in Bratislava.

Kasagranda, A., Rajčáková, E., \& Vystoupil, J. (2016). Urban Tourism in Slovakia - Its Quantification, Spatial Differentiation, and Typification. Geographica Pannonica, 21(2), 114-126. DOI: 10.18421/GP20.02-08.

Klamár, R. (2014). Tourism and the visit rate in the tourism regions in Eastern Slovakia from the point of selected indicators. Bulletin of Geography. Socio-economic Series, (23), 99-118. DOI: 10.2478/bog-2014-0007. 
Klamár, R., \& Kolesárová, J. (2015). Tourism Development and its Regionalization in the Prešov Self-Govering Region. Scientific Review of Physical Culture, 5(1), 65-79.

Krogmann, A. (2005). Aktuálne možnosti využitia územia Nitrianskeho kraja z hladiska cestovného ruchu (Actual Possibilities of Use of Area of Nitra County from the Tourism point of View). Acta Facultatis Rerum Naturalium Universitas Comenianae: Geographica, 28, 281-286.

Kršák, P. et al. (2009). Ottov historický atlas Slovensko (Otto’s Historical Atlas Slovakia). Prague, Czech Republic: Ottovo nakladatelství.

Kulla, M. (2007). Charakteristika vybraných foriem cestovného ruchu v meste Košice a v jeho zázemí (The Characteristics of Selected Forms of Tourism in Košice Town and Its Surroundings). Geographia Cassoviensis, 5(1), 73-78.

Kulla, M. (2011). Kúpel’níctvo na Slovensku - trendy a perspektívy (Spas in Slovakia - Trends And Perspectives). In V. Liška \& V. Navickas (Eds.), Význam l’udského potenciálu v regionálnom rozvoji (Importance of human potential in regional development) (pp. 117-122). Dudince, Slovak Republic: Eastern European Development Agency.

Kulla, M., \& Nedvid’ová, N. (2014). Hodnotenie zahraničnej návštevnosti mesta Košice v rokoch 2001 - 2012. In Sbornik recenzovaných přispěvku z 3. mezinárodni vědecké konference: Cestovni ruch, hotelnictvi a lázeňstvi ve světle vědeckého výzkumu a praxe (Proceedings of Reviewed contributions from the $3^{\text {rd }}$ International Scientific Conference: Tourism, Hotel and Spa in the Light of Scientific Research and Practice) (pp. 205-214). Karviná, Czech Republic: Slezská univerzita v Opavě.

Lauko, V. (1997). Fyzická geografia Slovenska I (Physical Geography of Slovakia). Bratislava, Slovak Republic: Comenius University in Bratislava.

Lauko, V., Španihel, M., \& Polčák, N. (2015). Analýza klimatických pomerov pre letnú rekreáciu v regiónoch cestovného ruchu Slovenska (Analysis of climate conditions for summer recreation in the tourism regions of Slovakia). In Pachrová \& Doležalová (Eds.), Aktuálne problémy v cestovnom ruchu (Actual problems in Tourism) (pp. 237-248). Jihlava, Czech Republic: College of Polytechnics Jihlava.

Marčeková, R., Kaščáková, A., \& Vránová, M. (2015). Segmentation of Wellness Tourism Visitors in Selected Regions in Slovakia. Czech Hospitality and Tourism Papers, 24(1), 5-18.

Mariot, P. (1983). Geografia cestovného ruchu (Geography of Tourism). Bratislava, Slovak Republic: Slovenská akadémia vied.

Mariot, P. (2001). Príspevok k typizácii stredísk cestovného ruchu (Contribution to the typification of the tourist resorts). Geografický časopis (Geographical Journal), 53(4), 307-319.

Masarovičová, A. (2014). História balneoterapie - stredovek (History of Balneotherapy - Middle Ages). Dermatológia pre prax (Dermatology for practice), 8(4), 150-152.

Masarovičová, A. (2015). História balneoterapie - novovek (History of Balneotherapy - Modern Age). Dermatológia pre prax, (Dermatology for practice), 9(2), 65-68.

Matlovičová, K., Kolesarová, J., \& Židová, A. (2013). Slovenské kúpelníctvo v kontexte zmien - aktuálny stav, problémy a výzvy (Slovak spas in the context of change - current conditions, issues and challenges). In M. Dej, M. Huculak, and W. Jarczewski (Eds.), Recreational use of geothermal water in Visegrad Group countries (pp. 161-173). Krakow, Poland: Institute of Urban Development.

Ministry of Health of SR. (2016). Inšpektorát kúpelov a žriediel: informácie o kúpelných miestach SR $v$ zmysle uzneseni a nariadeni vlády (Inspectorate of Spas and Springs: information on bathing sites within the meaning of SR resolutions and government regulations). Retrieved March 21, 2017, from http://www.health.gov.sk/?inspektorat-kupelov-a-zriediel-2.

Otrubová, E. (1999). Transformačné zmeny v slovenských kúpeloch (Transformation changes in Slovak Spas). Folia geographica, 3, 154-162. 
Plesník, P. (2008). Vymedzenie a ocenenie regiónov cestovného ruchu (Definition and appreciation of tourism regions). Bratislava, Slovak Republic: EKONÓM.

Šedivý, J. et al. (2012). Dejiny Bratislavy 1 : Brezalauspurc - na križovatke kultúr (The History of Bratislava 1: Brezalauspurc - At the Crossroads of Cultures). Bratislava, Slovak Republic: Slovart.

Slovakia.Travel.sk. (2015). Statistiky (Statistics). Retrieved December 16, 2015, from http://www. sacr.sk/sacr/statistiky.

Slovakia.travel.sk. (2016). Vybrané ukazovatele kúpel'ného cestovného ruchu na Slovensku v rokoch 2006 až 2015 (Selected indicators of spa tourism in Slovakia in years 2006 - 2015) - interné materiály (internal materials), Bratislava.

Smith, M., \& Puczkó, L. (2008). Health and Wellness Tourism. New York: Routledge.

Smolová, I., \& Szczyrba, Z. (2005). České lázně - tradiční produkt marketingu turistické destinace Česká republika (Czech spas - traditional marketing product of tourism destination Czech Republic). In Fňukal \& Ptáček (Eds.), Geografie cestovniho ruchu a rekreacie (Geography of tourism and recreation) (pp. 57-64). Olomouc, Czech Republic: Palacký University.

Stănciulescu, G. C., Diaconescu, G. N., \& Diaconescu, D. M. (2015). Health, Spa, Wellness Tourism. What Is The Difference? Knowledge Horizons - Economics, 7(3), 158-161.

Statistical Office of Slovak Republic. (2015). Vybrané ukazovatele kúpel'ného cestovného ruchu na Slovensku v rokoch 2009 až 2013 (Selected indicators of spa tourism in Slovakia in years 2009 - 2013). Bratislava.

Statistical Office of Slovak Republic. (2016). Vybrané ukazovatele kúpelného cestovného ruchu na Slovensku v rokoch 2006 až 2015 (Selected indicators of spa tourism in Slovakia in years 2006 - 2015). Bratislava.

Sudíková, L. (2009). Lázeňský cestovni ruch v České republice a Evropě (Spa tourism in Czech Republic and Europe). Master Thesis. Brno, Czech Republic: Masaryk University.

Vystoupil, J. et al. (2006). Atlas cestowniho ruchu České republiky (Atlas of tourism of the Czech Republic). Prague, Czech Republic: Ministry for Regional Development of the Czech Republic.

Vystoupil, J., \& Šauer, M. et al. (2011). Geografia cestovného ruchu České republiky (The Geography of tourism of Czech Republic). Plzeň, Czech Repulic: ALEŠ Čeněk Nakladatelství.

Vystoupil, J., Kasagranda, A., \& Šauer, M. (2016). Funkčně - prostorová typologie středisek cestovního ruchu Česka a Slovenska (Functional - spatial typology of tourist resorts in Czechia and Slovakia). Geografický časopis (Geographical Journal), 68(2), 171-192.

Weiss, P., Jankovičová, M., \& Kurčová, E. (2005). Regionalizácia cestovného ruchu v Slovenskej republike (Regionalization of Tourism of Slovak Republic). Bratislava, Slovak Republic: Ministry of Economy.

Zákon č. 538/2005 Z. z. o prírodných liečivých vodách, prírodných liečebných kúpeloch, kúpel’ných miestach a prírodných minerálnych vodách a o zmene a doplneni niektorých zákonov (Act no. 538/2005 Coll. about natural healing waters, natural healing spas, spa resorts and natural mineral waters and on amendments and supplements to some laws).

Zelenáková, O. (2014). Kúpele, termálne liečivé pramene a wellness v cestovnom ruchu Slovenska (Spas, thermal healing springs and wellness in tourism of Slovakia). Bachelor thesis. Brno, Czech Republic: Masaryk University.

Žoncová, M., Dubcová, A., Rampašeková, Z., \& Bobovnická, S. (2015). Akvaparky a wellness - nové trendy vo vývoji vodných destinácií na Slovensku (Aquaparks and wellness - new trends in development of water destination in Slovakia). In Pachrová \& Doležalová (Eds.), Aktuálne problémy v cestormom ruchu (Actual problems in Tourism) (p. 530-542). Jihlava, Czech Republic: College of Polytechnics Jihlava. 
Appendix 1 Accommodation infrastructure, guests, visitation rate and share of spa tourism

\begin{tabular}{|c|c|c|c|c|c|c|c|c|c|}
\hline YEAR & 200 & & 20 & & 20 & & 20 & & \\
\hline accommodation infrastructu & & & & & & & & & \\
\hline $\begin{array}{l}\text { number of accommodation } \\
\text { establishments }\end{array}$ & Total & $\begin{array}{l}+/- \\
{[\%]}\end{array}$ & Total & $\begin{array}{l}+/- \\
{[\%]}\end{array}$ & Total & $\begin{array}{l}+/- \\
{[\%]}\end{array}$ & Total & $\begin{array}{l}+/- \\
{[\%]}\end{array}$ & \\
\hline & 67 & 0 & 94 & 40.3 & 94 & 0 & 94 & 0 & \\
\hline rooms & 5,862 & -4.5 & 6,165 & 5.2 & 6,375 & 3.4 & 6,577 & 3.2 & \\
\hline beds & 11,314 & -4.2 & 11,916 & 5.3 & 12,370 & 3.8 & 12,793 & 3.4 & \\
\hline of which permanent & 11,214 & -4.7 & 11,611 & 3.5 & 12,056 & 3.8 & 12,492 & 3.6 & \\
\hline of which casual & 100 & 185.7 & 305 & 205 & 314 & 3 & 301 & -4.1 & \\
\hline guests and visitation rate & & & & & & & & & \\
\hline guests/tourists & $\begin{array}{l}\text { Total } \\
{[' 000]}\end{array}$ & $\begin{array}{l}+/- \\
{[\%]}\end{array}$ & $\begin{array}{l}\text { Total } \\
{\left[{ }^{\prime} 000\right]}\end{array}$ & $\begin{array}{l}+/- \\
{[\%]}\end{array}$ & $\begin{array}{l}\text { Total } \\
{[' 000]}\end{array}$ & $\begin{array}{l}+/- \\
{[\%]}\end{array}$ & $\begin{array}{l}\text { Total } \\
{\left[{ }^{\prime} 000\right]}\end{array}$ & $\begin{array}{l}+/- \\
{[\%]}\end{array}$ & \\
\hline & 253.26 & 10.7 & 276.16 & 9.0 & 284.81 & 3.1 & 241.31 & -15.3 & \\
\hline of which domestic & 159.34 & 13.9 & 178.90 & 12.3 & 192.05 & 7.4 & 180.98 & -5.8 & \\
\hline of which international & 93.92 & 5.6 & 97.27 & 3.6 & 92.76 & -4.6 & 60.33 & -35 & \\
\hline overnight stays & $2,277.19$ & 5.9 & $2,453.29$ & 7.7 & $2,606.85$ & 6.3 & $2,391.09$ & -8.3 & \\
\hline of which domestic & $1,423.92$ & 8.8 & $1,600.11$ & 12.4 & $1,815.62$ & 13.5 & $1,841.26$ & 1.4 & \\
\hline of which international & 853.27 & 1.3 & 853,18 & 0.0 & 791.23 & -7.3 & 549.83 & -30.5 & \\
\hline average length of stay* & 9.0 & -4.4 & 8.9 & -1.0 & 9.2 & 2.8 & 9.9 & 8.3 & \\
\hline of which domestic & 8.9 & -4.5 & 8.9 & -0.4 & 9.5 & 6.2 & 10.2 & 7.6 & \\
\hline of which international & 9.1 & -4 & 8.8 & -3.1 & 8.5 & -3.1 & 9.1 & 6.8 & \\
\hline share of spa tourism in Slov & sm & & & & & & & & \\
\hline $\begin{array}{l}\text { share of overnight } \\
\text { stays of Slovakia }\end{array}$ & $\begin{array}{c}\text { Total } \\
{[\%]}\end{array}$ & $\begin{array}{l}+/- \\
{[\%]}\end{array}$ & $\begin{array}{l}\text { Total } \\
{[\%]}\end{array}$ & $\begin{array}{l}+/- \\
{[\%]}\end{array}$ & $\begin{array}{c}\text { Total } \\
{[\%]}\end{array}$ & $\begin{array}{l}+/- \\
{[\%]}\end{array}$ & $\begin{array}{c}\text { Total } \\
{[\%]}\end{array}$ & $\begin{array}{l}+/- \\
{[\%]}\end{array}$ & \\
\hline & 20.4 & 2.0 & 21.2 & 3.7 & 20.9 & -1.4 & 23.0 & 10.0 & \\
\hline of which domestic & 23.7 & 6.2 & 25.1 & 6.0 & 25.2 & 0.3 & 27.8 & 10.3 & \\
\hline of which international & 16.6 & -3.8 & 16.4 & -1.3 & 15.0 & -8.4 & 14.6 & -3.0 & \\
\hline $\begin{array}{l}\text { share of guests/tourists of } \\
\text { Slovakia }\end{array}$ & 7.1 & 5.9 & 7.3 & 3.4 & 7.0 & -4.6 & 7.1 & 2.3 & \\
\hline of which domestic & 8.1 & 10.5 & 8.5 & 5.8 & 8.3 & -3.0 & 8.7 & 4.8 & \\
\hline of which international & 5.8 & -0.7 & 5.8 & -0.9 & 5.3 & -9.1 & 4.6 & -11.5 & \\
\hline
\end{tabular}

*average length of stay is evaluated in days

Source: Statistical Office of the Slovak Republic (2016) - authors' own processing 


\section{in Slovakia in selected years}

2010

2011

2012

2013

2014

2015

\begin{tabular}{|c|c|c|c|c|c|c|c|c|c|c|c|}
\hline Total & $\begin{array}{l}+/- \\
{[\%]}\end{array}$ & Total & $\begin{array}{l}+/- \\
{[\%]}\end{array}$ & Total & $\begin{array}{l}+/- \\
{[\%]}\end{array}$ & Total & $\begin{array}{l}+/- \\
{[\%]}\end{array}$ & Total & $\begin{array}{l}+/- \\
{[\%]}\end{array}$ & Total & $\begin{array}{l}+/- \\
{[\%]}\end{array}$ \\
\hline 94 & 0 & 89 & -5.3 & 100 & 12.4 & 101 & 1 & 99 & -2 & 101 & 2 \\
\hline 6,114 & -7 & 6,003 & -1.8 & 6,101 & 1.6 & 6,346 & 4 & 6,448 & 1.6 & 6,622 & 2.7 \\
\hline 12,021 & -6 & 11,795 & -1.9 & 11,841 & 0.4 & 12,302 & 3.9 & 12,888 & 4.8 & 13,142 & 2 \\
\hline 11,707 & -6.3 & 11,481 & -1.9 & 11,558 & 0.7 & 12,069 & 4.4 & 12,468 & 3.3 & 12,699 & 1.9 \\
\hline 314 & 4.3 & 314 & 0 & 283 & -9.9 & 233 & -17.7 & 420 & 180 & 443 & 1.1 \\
\hline
\end{tabular}

\begin{tabular}{|c|c|c|c|c|c|c|c|c|c|c|c|}
\hline $\begin{array}{c}\text { Total } \\
\text { ['000] }\end{array}$ & $\begin{array}{l}+/- \\
{[\%]}\end{array}$ & $\begin{array}{l}\text { Total } \\
\text { ['000] }\end{array}$ & $\begin{array}{l}+/- \\
{[\%]}\end{array}$ & $\begin{array}{l}\text { Total } \\
\text { ['000] }\end{array}$ & $\begin{array}{l}+/- \\
{[\%]}\end{array}$ & $\begin{array}{l}\text { Total } \\
\text { ['000] }\end{array}$ & $\begin{array}{l}+/- \\
{[\%]}\end{array}$ & $\begin{array}{l}\text { Total } \\
\text { ['000] }\end{array}$ & $\begin{array}{l}+/- \\
{[\%]}\end{array}$ & $\begin{array}{l}\text { Total } \\
\text { ['000] }\end{array}$ & $\begin{array}{l}+/- \\
{[\%]}\end{array}$ \\
\hline 259,51 & 7.5 & 261.52 & 0.8 & 256.38 & -2.0 & 278.43 & 8.6 & 299.03 & 7.4 & 304.98 & 2.0 \\
\hline 194.71 & 7.6 & 196.09 & 0.7 & 194.50 & -0.8 & 210.31 & 8.1 & 230.34 & 9.5 & 241.70 & 4.9 \\
\hline 64.80 & 7.4 & 65.43 & 1.0 & 61.88 & -5.4 & 68.12 & 10.1 & 68.69 & 0.8 & 63.27 & -7.9 \\
\hline $2,490.04$ & 4.1 & $2,412.11$ & -3.1 & $2,381.60$ & -1.3 & $2,547.51$ & 7.0 & $2,617.21$ & 2.7 & $2,612.79$ & -0.2 \\
\hline $1,934.98$ & 5.1 & $1,890.64$ & -2.3 & $1,858.32$ & -1.7 & $1,978.34$ & 6.5 & $2,067.58$ & 4.5 & $2,107.91$ & 2.0 \\
\hline 555.06 & 1.0 & 521.47 & -6.1 & 523.28 & 0.3 & 569.17 & 8.8 & 549.63 & -3.4 & 504.87 & -8.1 \\
\hline 9.6 & -3.2 & 9.2 & -3.9 & 9.3 & 0.7 & 9.1 & -1.5 & 8.8 & -4.3 & 8.6 & -2.1 \\
\hline 9.9 & -2.3 & 9.6 & -3.0 & 9.6 & -0.9 & 9.4 & -1.5 & 9.0 & -4.6 & 8.7 & -2.8 \\
\hline 8.6 & -6.0 & 8.0 & -7.0 & 8.5 & 6.1 & 8.4 & -1.2 & 8.0 & -4.2 & 8.0 & -0.3 \\
\hline
\end{tabular}

\begin{tabular}{|c|c|c|c|c|c|c|c|c|c|c|c|}
\hline $\begin{array}{c}\text { Total } \\
{[\%]}\end{array}$ & $\begin{array}{l}+/- \\
{[\%]}\end{array}$ & $\begin{array}{c}\text { Total } \\
{[\%]}\end{array}$ & $\begin{array}{l}+/- \\
{[\%]}\end{array}$ & $\begin{array}{c}\text { Total } \\
{[\%]}\end{array}$ & $\begin{array}{l}+/- \\
{[\%]}\end{array}$ & $\begin{array}{c}\text { Total } \\
{[\%]}\end{array}$ & $\begin{array}{l}+/- \\
{[\%]}\end{array}$ & $\begin{array}{c}\text { Total } \\
{[\%]}\end{array}$ & $\begin{array}{l}+/- \\
{[\%]}\end{array}$ & $\begin{array}{c}\text { Total } \\
{[\%]}\end{array}$ & $\begin{array}{l}+/- \\
{[\%]}\end{array}$ \\
\hline 24.0 & 4.4 & 22.9 & -4.6 & 21.8 & -4.7 & 23.4 & 7.0 & 24.0 & 2.8 & 21.2 & -11.9 \\
\hline 29.5 & 6.1 & 29.1 & -1.2 & 27.3 & -6.3 & 29.1 & 6.5 & 29.6 & 1.7 & 26.7 & -9.5 \\
\hline 14.6 & 0.0 & 12.9 & -11.4 & 12.8 & -1.2 & 13.9 & 8.8 & 14.1 & 1.4 & 11.3 & -19.7 \\
\hline 7.6 & 7.2 & 7.3 & -4.3 & 6.8 & -7.2 & 7.4 & 8.6 & 8.0 & 8.7 & 7.0 & -12.2 \\
\hline 9.4 & 8.5 & 9.3 & -1.4 & 8.7 & -6.8 & 9.4 & 8.1 & 10.2 & 9.2 & 9.3 & -9.2 \\
\hline 4.9 & 5.1 & 4.5 & -8.3 & 4.1 & -9.6 & 4.5 & 10.1 & 4.7 & 4.4 & 3.7 & -21.3 \\
\hline
\end{tabular}

